\begin{tabular}{l|l|l} 
Jurnal Eksplorasi Akuntansi & $\begin{array}{l}\text { ISSN : 2656-3649 (Online) } \\
\text { Vol. 2, No 1, Seri A, Februari 2020, Hal 2051-2064:/jea.ppj.unp.ac.id/index.php/jea/issue/view/17 }\end{array}$
\end{tabular}

\title{
PENGARUH PERSISTENSI LABA DAN KUALITAS AKRUAL TERHADAP EARNINGS RESPONSE COEFFICIENT PADA PERUSAHAAN MANUFAKTUR DAN KEUANGAN YANG TERDAFTAR DI BEI TAHUN 2016-2018
}

\author{
Brigita Ahabba $^{1}$, Nurzi Sebrina ${ }^{2}$ \\ ${ }^{1}$ Alumni Jurusan Akuntansi Fakultas Ekonomi Universitas Negeri Padang \\ ${ }^{2}$ Jurusan Akuntansi Fakultas Ekonomi Universitas Negeri Padang \\ *Korespondensi: brigitaahabba@gmail.com
}

\begin{abstract}
This study aims to examine the effect of earnings persistence and accrual quality on earnings response coefficient. The sample used was manufacturing and financial sector companies listed on the Stock Exchange in 2016-2018 with a sampling method that was purposive sampling, so sample was obtaines is 92 manufacturing companies and 61 financial companies. The results of this study are first, earnings persistence has a negative and not significant effect on ERC in the manufacturing sector, while a significant positive effect on ERC in the financial company sector, so these variables can determine the level of ERC. Second, accrual quality has a positive and insignificant effect on ERC in the two corporate sectors.
\end{abstract}

Keywords : Accrual Quality; Earnings Persistance; Earnings Response Coefficient; Earnings Quality; Fair Value

How to cite (APA $6^{\text {th }}$ style):

Ahabba, Brigita \& Sebrina, Nurzi. (2020). Pengaruh Persistensi Laba dan Kualitas Akrual Terhadap Earnings Response Coefficient Pada Perusahaan Manufaktur dan Keuangan Yang Terdaftar di BEI Tahun 2016-2018. Jurnal Eksplorasi Akuntansi, 2(1), Seri A, 2051-2064.

\section{PENDAHULUAN}

Perusahaan menyajikan laporan keuangan kepada stakeholder untuk memberikan informasi yang tepat waktu dan relevan terkait kinerja perusahaan, agar dapat digunakan dalam mengambil keputusan baik untuk tujuan kontrak (contracting decision) atau keputusan investasi (investment desicion) (Shipper dan Vincent, 2003). Reaksi yang ditunjukkan oleh investor saat penyajian laporan keuangan dapat berbeda-beda, sesuai dengan tingkat informasi yang tersedia dan kemampuan investor dalam memaknai informasi tersebut. Reaksi ini dapat tergambar dari keputusan investor dalam membeli, menjual atau menahan sekuritas ketika menerima informasi laba yang diterbitkan oleh perusahaan (Scott, 2015). 
Eficiency Market Theory menyatakan pasar akan bereaksi cepat terhadap informasi yang baru, sehingga informasi angka laba akan mempengaruhi keputusan investor. Reaksi pasar terhadap informasi laba yang dipublikasikan oleh perusahaan akan dapat diamati dari pergerakan harga saham sekitar tanggal publikasi laporan keuangan dan dapat diukur menggunakan earnings reponse coefficient (ERC) (Tandelilin, 2010). ERC akan menilai keinformatifan dan kualitas laba berdasarkan respon pasar terhadap pengumuman laba. Dalam memaknai informasi laba, investor tidak hanya fokus pada besar atau kecilnya laba tetapi akan memperhatikan bagaimana laba terbentuk. Laba dikatakan berkualitas jika disajikan sebaik-baiknya, menggambarkan kinerja perusahaan dan mencerminkan keberlanjutan laba (sustainable earnings). Kualitas laba sering digambarkan dengan persistensi laba, karena dianggap sebagai komponen karakteristik kualitatif relevansi (Jonas dan Blanchet, 2000).

Persistensi laba dapat dilihat dari bagaimana inovasi laba tahun berjalan dan dihubungkan dengan perubahan harga saham (Scott, 2015). Persistensi laba yang tinggi akan berdampak terhadap besarnya reaksi pasar karena investor merasa lebih yakin dalam membuat keputusan, menurut Palupi (2006) nilai ERC diprediksi akan semakin tinggi jika laba yang disampaikan berkualitas dan persisten. Perubahan pada Standar Akuntansi Keuangan (SAK) setelah mengadopsi IFRS dapat menyebabkan terjadinya perubahan kualitas laba antara sebelum dan sesudah pengadopsian IFRS. Standar principle base yang digunakan dalam IFRS akan lebih banyak menggunakan judgment dibandingkan aturan baku. Penilaian akuntansi termasuk fair value akan lebih kepada pandangan subjektif, yang akan memungkinkan peluang manajemen untuk melakukan discretionary accrual (Bangun, 2014).

Investor harus memperhatikan hal-hal yang tidak diungkapkan dalam informasi laba seperti kualitas akrual, untuk menghindari salahnya pengambilan keputusan. Kualitas akrual dapat dibedakan menjadi dua proksi yakni kualitas akrual innate dan kualitas akrual diskresioner. Kualitas akrual innate adalah kualitas akrual yang dihasilkan dari operasional perusahaan, sedangkan kualitas akrual diskresioner didapatkan dari keputusan yang dibuat oleh manajer (Francis et al., 2004). Investor akan cenderung baik dalam merespon informasi laba jika, informasi laba bebas dari gangguan persepsian yakni penerapan akrual yang berbeda untuk transaksi yang sama. Penelitian Gaol (2012), Novianti (2012) menyebutkan adanya hubungan yang signifikan positif antara kualitas akrual dengan earnings response coefficient (ERC).

Kualitas laba sebenarnya tidak dapat diobservasi secara langsung dan tepat, tetapi dapat diukur melalui proksi-proksi yang melekat pada laba seperti seperti persistensi laba, kualitas akrual, kesempatan bertumbuh dan risiko sistematik (Scott, 2015). Pada penelitian kali ini akan melihat bagaimana pengaruh persistensi laba dan kualitas akrual terhadap informasi laba yang akan diukur dengan bagaimana respon atau tindakan investor (earnings response coefficient), yang akan tercermin dalam harga saham sekitar tanggal publikasi laporan keuangan. Scott (2015) menjelaskan respon investor dalam menerima informasi akan berbeda tergantung kepada kapabilitas masing-masing individu, hal ini juga akan berlaku bagi investor dalam pasar modal indonesia. Dengan adanya penelitian ini diharapkan akan dapat memberikan gambaran bagaimana investor dalam merespon informasi laba perusahaan, karena angka laba yang tinggi tidak akan menandakan laba tersebut berkualitas.

Setelah penerapan PSAK 1 (revisi 2010), laba suatu perusahaan bukan hanya net income tetapi ada ukuran laba lain yakni comprehensive income yang dinilai lebih relevan. Laporan laba rugi komprehensif akan mencakup tentang pendapatan komprehensif lain yang tidak diakui pada laporan laba rugi, yang secara langsung menjadikan laba komprehensif lebih bersifat relevan. 
Peneliti menggunakan ukuran laba komprehensif pada dua sektor ini, karena pada perusahaan laba komprehensif cenderung lebih memberikan pengaruh yang cukup kuat atau memiliki relevansi nilai yang lebih terhadap nilai perusahaan yang tergambar melalui ERC (Winelfia, 2016).

Dari latar belakang yang telah dijelaskan diatas, maka penulis tertarik untuk mengangkat judul penelitian "Pengaruh Persistensi Laba dan Kualitas Akrual terhadap Earnings Response Coefficient pada Perusahaan Manufaktur dan Keuangan" yang terdapat di Bursa Efek Indonesia tahun 2016-2018.

\section{REVIU LITERATUR DAN PENGEMBANGAN HIPOTESIS Teori Pasar Efisien}

Efficiency Market Hypotesis (EMH) menjelaskan bahwa perubahan harga saham pada pasar efisien mengikuti pola random walk, dimana perkiraan harga tidak bisa dilihat dari harga historis tetapi berdasarkan pada semua informasi yang tersedia. Dalam pasar efisien harga akan sepenuhnya mencerminkan informasi yang tersedia, dan akan bereaksi dengan seketika tanpa ada bias terhadap informasi baru (Tandelilin, 2010). Dalam pasar efisien informasi akuntansi akan bersaing dengan informasi lainnya seperti analis keuangan (financial analysts), berita (news), bahkan harga pasar itu sendiri. Informasi akuntansi akan dipandang oleh investor jika informasi akuntansi itu relevan, reliabel, tepat waktu (timely), hemat biaya jika dibandingkan dengan memperoleh informasi lain.

\section{Laba Komprehensif}

Laba rugi komprehensif merupakan salah satu unsur laporan keuangan yang memberikan informasi mengenai laba bersih dan pendapatan komprehensif lainnya (Harimurti dan Hidayat, 2013). Pendapatan komprehensif (OCI) akan berisi pos-pos penyesuaian reklasifikasi yang tidak diakui dalam laporan laba rugi atau tidak memiliki hubungan langsung dengan operasi normal perusahaan.

\section{Earnings Response Coefficient}

Earnings response coefficient adalah ukuran besaran return abnormal suatu sekuritas sebagai bentuk respon terhadap komponen laba kejutan (unexpected earnings) (Scott, 2015). Tinggi dan rendahnya earnings response coefficient tergantung bagaimana investor memaknai laba apakah good news atau bad news. Respon pasar terhadap informasi laba akan berbeda, hal ini dapat disebebkan oleh beberapa faktor yaitu beta, persistensi laba, kualitas laba, struktur modal, kesempatan bertumbuh (growth opportunities), dan ukuran perusahaan (Scott, 2015). Menurut Rahmawati (2012) semakin besar earnings reponse coefficient menandakan semakin kuat hubungan antara abnormal return dengan unexpected earnings.

\section{Persistensi Laba}

Kualitas laba yang tinggi juga banyak disampaikan dengan laba yang sustainable dimana juga sebagai sinonim dari persistence (Schipper and Vincent, 2003). Persistensi laba dapat digunakan sebagai salah satu alat ukur laba karena laba yang berkualitas dapat ditunjukkan dengan kesinambungan laba itu sendiri (Wijayanti, 2006). Persistensi laba merupakan harapan laba dimasa yang akan datang (expected future earnings) yang diimplikasikan oleh laba sekarang atau 
laba tahun berjalan (current earnings). Persistensi laba akuntansi dapat diukur menggunakan koefisien regresi antar laba (Pangalung, 2006).

\section{Kualitas Akrual}

Laba akuntansi yang dikatakan berkualitas jika laba tersebut bebas dari persepsian (peceived noise) dan dapat mencerminkan kinerja perusahaan (Schipper dan Vincent, 2003). Hayn (1995) laba akuntansi yang mengandung gangguan persepsian dapat disebabkan oleh penerapan konsep akrual dalam akuntansi. Semakin besarnya gangguan persepsian ini menyebabkan semakin rendah kualitas laba akuntansi yang tersedia. Terdapat dua komponen yang dapat membedakan kualitas akrual yakni akrual innate atau akrual yang dipengaruhi oleh kondisi operasional perusahaan dan akrual discretionary dimana akrual dapat menjadi subjek keleluasaan dari pihak manajemen (managerial discretion) dan akan merefleksikan kebijakan akuntansi yang dijalankan oleh perusahaan. (Francis et al, 2004).

\section{Persistensi laba dan ERC}

Scott (2015) menjelaskan bahwasanya persistensi laba merupakan laba yang diharapkan dimasa yang akan datang (expected future earnings) yang dapat dilihat dari inovasi laba tahun berjalan. Sejalan dengan PSAK I Revisi 2009 yang mewajibkan perusahaan untuk menyajikan laporan laba rugi komprehensif, pada penelitian ini akan dilihat dari laba komprehensif perusahaan manufaktur dan perusahaan keuangan karena memiliki relevansi nilai yang lebih baik. Semakin tingginya koefisien respon laba akan berjalan searah dengan semakin tingginya persistensi laba perusahaan yang mengindikasikan laba berkualitas. Sejalan dengan penelitian Palupi (2006), Mulyani (2007), Li (2008), dan Delvira (2013) yang menyatakan persistensi laba berpengaruh signifikan positif terhadap ERC. Berdasarkan uraian diatas maka dapat dirumuskan hipotesis 1 adalah sebagai berikut:

H1: Persistensi laba komprehensif berpengaruh signifikan positif terhadap Earnings Response Coefficien.

\section{Kualitas Akrual dan ERC}

Dengan meningkatnya kualitas informasi yang terbentuk dari kualitas akrual yang tinggi, yang akan menyebabkan informasi tersebut relevan digunakan untuk mengambil keputusan (Boediono, 2005). Dalam pengakuan laba, akrual secara langsung akan mempengaruhi angka laba yang dihasilkan oleh perusahaan. Penelitian ini menggunakan perusahaan manufaktur dan keuangan, karena pada perusahaan manufaktur kemungkinan untuk menerapkan managerial discretion lebih besar dibandingkan perusahaan keuangan (Francis et.al, 2004). Semakin bagusnya kualitas akrual suatu perusahaan maka akan menyajikan informasi laba yang lebih berkualitas, karena dengan akrual yang baik akan didapatkan pedoman lebih pasti tentang revenue recognition dan expense matching. Penelitian dari Gaol (2011), Novianti (2012) yang menunjukkan hasil bahwa kualitas akrual yang tinggi mempengaruhi besarnya respon investor tehadap informasi laba. Berdasarkan uraian diatas dirumuskan hipotesis 2 sebagai berikut:

H2: Kualitas akrual berpengaruh signifikan positif terhadap Earnings Response Coefficient. 
Hubungan antara variabel dari penelitian ini dapat digambarkan sebagai berikut:

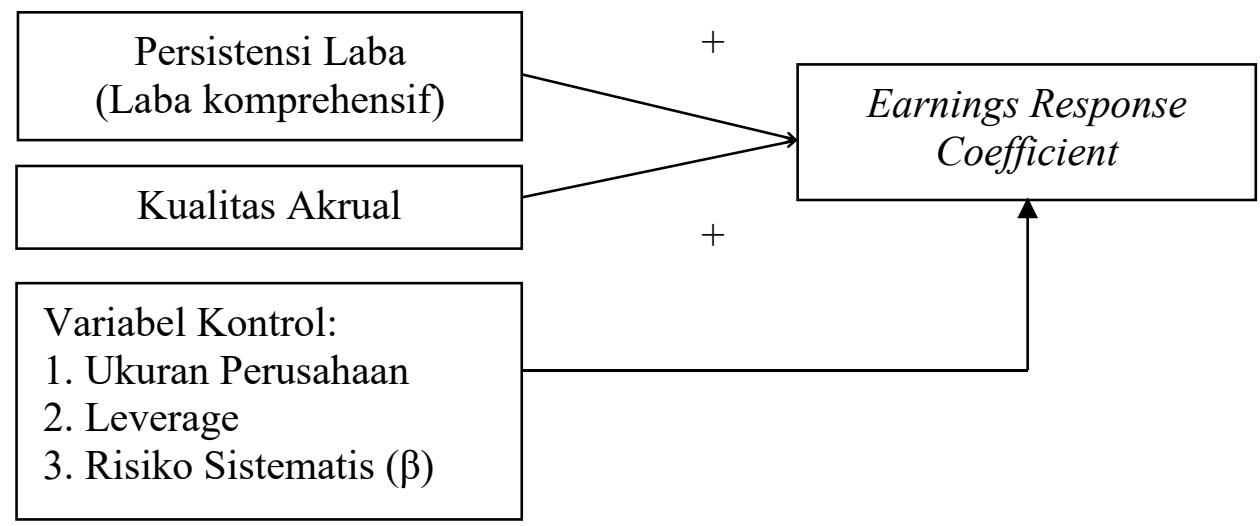

Gambar 1

Kerangka Konseptual

\section{METODE PENELITIAN}

\section{Jenis Penelitian}

Penelitian ini tergolong kepada penelitian kausatif, dimana berguna untuk menganalisis seberapa jauh variabel bebas mempengaruhi variabel terikat, dan bagaimana pengaruhnya.

\section{Populasi dan Sampel}

Populasi yang diambil pada penelitian kali ini adalah perusahaan manufaktur dan perusahaan keuangan yang terdapat di Bursa Efek Indonesia (BEI) dari tahun 2016 sampai dengan tahun 2018 yang memenuhi syarat pada penelitian, berdasarkan hasil tabulasi data, maka diperoleh sampel 92 perusahaan manufaktur dan 63 perusahaan keuangan. Metode pemilihan sampel adalah purposive sampling, dengan kriteria sampel:

\section{Tabel 1}

Kriteria Sampel Perusahaan

\begin{tabular}{ccc}
\hline & Perusahaan Manufaktur & Perusahaan Keuangan \\
\hline Jumlah perusahaan di BEI & 168 & 89 \\
Perusahaan yang listing sejak 2016 sampai dengan & $(25)$ & $(6)$ \\
2018 & & $(22)$ \\
Menghasilkan laba berturut-turut dari tahun 2016 \\
$\begin{array}{c}\text { sampai dengan 2018 } \\
\text { Total sampel perusahaan }\end{array}$ & 92 & 61 \\
\hline
\end{tabular}

\section{Jenis dan Sumber Data}

Jenis data pada penelitian ini adalah sekunder atau data dokumenter perusahaan yang listing di BEI dari tahun 2016-2018.

\section{Variabel Penelitian dan Pengukuran}

\section{a. Earnings Response Coefficient}

Pada penelitian ini proksi harga saham yang digunakan adalah CAR dan proksi laba akuntansi yang digunakan adalah UE. 


$$
C A R_{i t}=\alpha_{0}+\alpha_{1} U E_{i t}+\text { controls } \Gamma_{i t}+\varepsilon_{i t}
$$

Dari model diatas $\alpha_{1}$ akan menggambarkan besarnya nilai koefisien respon laba.

\section{- Cummulative Abnormal Return (CAR)}

Menghitung CAR dilakukan dengan beberapa tahap perhitungan :

1. Return Abnormal

$$
A R_{i t}=R_{i t}-R_{\text {mit }}
$$

$A R_{i t}=$ Return Abnormal perusahaan i pada periode ke-t

$R_{i t} \quad=$ Return sesungguhnya perusahaan i pada hari-t

$R_{m i t}=$ Return pasar perusahaan i pada hari-t

\section{Return Sesungguhnya}

$$
R_{i t}=\frac{P_{i t}-P_{i t-1}}{P_{i t-1}}
$$

$P_{i t} \quad=$ Closing price perusahaan i pada hari ke-t

$P_{i t-1}=$ Closing price perusahaan i pada hari sebelum- $\mathrm{t}$

\section{Return Pasar}

$$
R M_{i t}=\frac{I H S G_{t}-I H S G_{t-1}}{I H S G_{t-1}}
$$

$R M_{i t}=$ Return pasar pada hari ke-t

$I H S G_{t}=$ IHSG pada hari- $\mathrm{t}$

$I H S G_{t-1}=$ IHSG pada hari sebelum-t

\section{CAR}

$$
C A R_{i t}=C A R(-3,+3)=\sum_{T=-3}^{+3} A R_{i t}
$$

$C A R_{i t}=$ Cummulative Abnormal Return perusahaan i pada tahun ke-t

- Unexpected Earnings (UE)

$$
U E_{i t}=\frac{E P S_{t}-E P S_{t-1}}{E P S_{t-1}}
$$

$U E_{i t} \quad=U E$ perusahaan i pada tahun ke-t

$E P S_{t}=$ Laba akuntansi perusahaan i pada tahun ke-t

$E P S_{t-1}=$ Laba akuntansi perusahaan i sebelum tahun ke-t

\section{b. Persistensi Laba}

Diukur dengan koefisien regresi antara laba akuntansi perusahaan sekarang dengan laba akuntansi perusahaan periode sebelumnya (Francis et al., 2004), dengan rumus : 


$$
E_{i t}=\beta_{0}+\beta_{1} E_{i t-1}+\varepsilon_{i t}
$$

Persistensi laba akan tergambar melalui $\beta_{1}$ yang apabila $>1$ dikatakan high persistent, $>0$ persisten dan $<0$ tidak persisten atau fluktuatif.

\section{c. Kualitas Akrual}

Penelitian ini menggunakan Dechow dan Dichev model (2002) dengan rumus :

$$
\Delta W C_{t}=\alpha+\beta_{1} C F O_{t-1}+\beta_{2} C F O_{t}+\beta_{3} C F O_{t+1}+e_{t}
$$

$$
\begin{aligned}
& \Delta W C_{t}=\text { aset }- \text { liabilities } \\
& C F O_{t}=\text { Arus kas dari kegiatan operasional pada periode (tahun) ke-t }
\end{aligned}
$$

Dari model diatas besaran kualitas akrual akan tergambar dari besar standar diviasi residual, yang selanjutnya akan dikalikan dengan -1. Semakin tinggi nilai residual maka akan semakin rendah kualitas akrualnya.

\section{Variabel Kontrol}

\section{Ukuran Perusahaan}

Dalam penelitian ini ukuran perusahaan diproksi menggunakan logaritma natural total aset (Ln total aset).

\section{Leverage}

Leverage digunakan untuk mengukur seberapa jauh perusahaan bergantung kepada pihak kreditor dalam membiayai aset perusahaan. Variabel ini diproksi dengan DER (Total hutang dibagi ekuitas).

\section{Risiko Sistematik}

Teori koefisien beta menyatakan risiko sistematik secara kuantitatif disebut dengan beta. Koefisien beta dapat diperoleh dengan rumus (Suad, 2005):

$$
R=\alpha+\beta R M+e
$$

$\mathrm{R} \quad=$ Return saham

$\beta \quad=$ Beta saham (risiko sistematis)

RM $\quad=$ Return pasar

\section{Teknik Analisis Data}

\section{Analisis Deskriptif}

Analisis ini bertujuan untuk menggambarkan apa yang ditemukan pada hasil penelitian dan memberikan informasi sesuai dengan apa yang diperoleh di lapangan. Teknik deskriptif yang dimaksudkan dalam penelitian ini adalah untuk menginterprestasikan nilai maksimum, minimum, mean dan standar deviasi dari masing-masing variabel penelitian. 


\section{Analisis Regresi Berganda}

Analisis regresi berganda ini bertujuan untuk mengatahui bagaimana hubungan hubungan variabel dependen dengan variabel independen baik itu satu, dua atau lebih. Digunakan persamaan regresi berganda sebagai berikut:

\section{Persamaan Pertama}

Digunakan untuk melihat bagaimana hubungan variabel persistensi laba terhadap ERC. Persamaan pertama ini akan menjawab hipotesis 1 .

$$
C A R_{i t}=\alpha_{0}+\alpha_{1} U E_{i t}+\alpha_{2} P S_{i t}+\alpha_{3} U E_{i t} * P S_{i t}+\text { Control }_{i t}+\varepsilon_{i t}
$$

\section{Persamaan Ke-dua}

Digunakan untuk melihat bagaimana hubungan variabel kualitas akrual terhadap ERC. Persamaan ke-dua ini akan menjawab hipotesis 2.

$$
C A R_{i t}=\alpha_{0}+\alpha_{1} U E_{i t}+\alpha_{2} A C C_{i t}+\alpha_{3} U E_{i t} * A C C_{i t}+\text { Controls }_{i t}+\varepsilon_{i t}
$$

\section{Persamaan Ke-tiga}

Persamaan ke-tiga ini digunakan untuk melihat bagaimana pengaruh kedua variabel independen terhadap ERC, dengan cara menginteraksikannya.

$$
C A R_{i t}=\alpha_{0}+\alpha_{1} U E_{l t}+\alpha_{2} P S_{i t}+\alpha_{3} A C C_{t t}+\alpha_{4} U E_{t t} * P S_{i t}+\alpha_{5} U E_{t t}^{*} A C C_{i t}+\text { Contro } \mathbb{I}_{t t}+\varepsilon_{i t}
$$

Keterangan :

$\mathrm{CAR}=$ Cummilative Abnormal Return

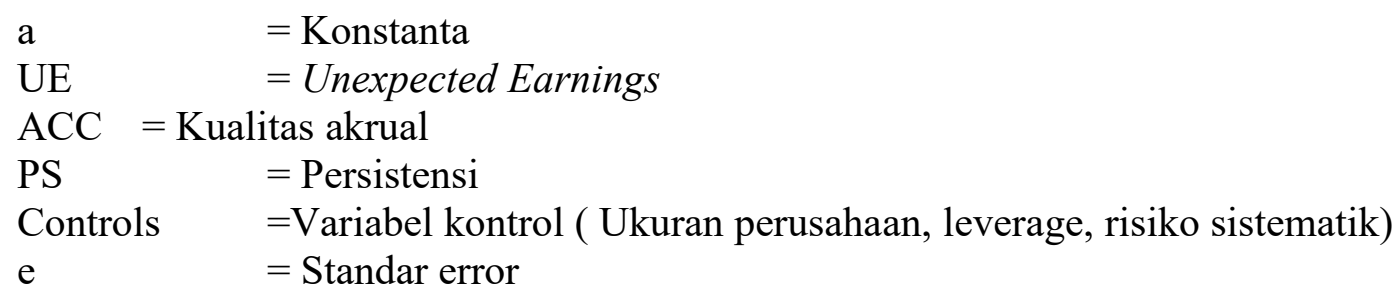

\section{HASIL DAN PEMBAHASAN \\ Statistik Deskriptif}

Setelah dilakukan tabulasi sampel dengan empat kriteria pemilihan sampel, maka diperoleh 92 sampel data perusahaan manufaktur dan 61 sampel data perusahaan keuangan dari tahun 20162018. Namun ditemukan beberapa data outlier pada sampel yakni 40 perusahaan manufatur dan 20 perusahaan keuangan. Lampiran 3 menyajikan statistik deskriptif untuk melihat nilai maksimum, minimum, mean, median dan standar deviasi dari masing-masing variabel penelitian.

\section{Uji Asumsi Klasik}

Uji Normalitas Residual

Pengujian normalitas bertujuan untuk apakah sebuah data mendekati atau berdistribusi normal. Data dikatakan terdistribusi dengan normal jika Jarque-Bera $<2$ dan Sig $>0,05$. Hasil pengujian ini dapat dilihat pada lampiran 3, dimana pengolahan data diperoleh hasil perusahaan manufaktur dan keuangan telah terdistribusi dengan normal. 


\section{Uji Multikolinearitas}

Uji multikolinearitas ini dilakukan untuk mengetahui apakah terdapat korelasi antara variabelvariabel indipenden. Multikolinearitas dapat diuji menggunakan Variance Inflation Factor (VIF) dan Tolerance Value, jika didapatkan hasil VIF diatas atau $>10$ dan TF dibawah atau $<0,10$ maka terjadi multikolinearitas. Hasil pengujian ini dapat dilihat pada lampiran 3, dimana data pada perusahaan manufaktur dan keuangan tidak terjadi multikolinearitas.

\section{Uji Heteroskedastisitas}

Bertujuan untuk melihat apakah dalam model regresi terjadi ketidaksamaan varians suatu pengamatan kepada pengamatan yang lainnya. Uji glejser adalah salah satu bentuk pengujian yang dapat digunakan untuk menguji heteroskedastisitas. Jika hasil tidak signifikan ( 1 ig $>0,05)$, berarti model penelitian bebas dari heteroskedastisitas. Hasil pengujian ini dapat dilihat pada lampiran 3, hasil pengujian data perusahaan manufaktur dan keuangan didapatkan perhitungan bahwa tidak terjadi masalah heteroskedastisitas.

\section{Uji Autokorelasi}

Uji autokorelasi bertujuan menguji apakah dalam model regresi linear ada korelasi antara kesalahan pengganggu pada periode $\mathrm{t}$ dengan kesalahan pengganggu pada periode $\mathrm{t}-1$ (sebelumnya) dengan nilai D-W antara -2 sampai 2. Hasil pengujian dapat dilihat pada lampiran 3, dimana dapat disimpulkan bahwa tidak terdapat autokorelasi.

\section{Uji Kelayakan Model}

\section{Uji Koefisien Determinasi}

Uji koefisien determinasi $\left(R^{2}\right)$ akan mengukur persentase varians dari variabel dependen yang akan dijelaskan pengaruhnya oleh variabel indipenden. Nilai koefisien determinasi $\left(R^{2}\right)$ terletak antara 0 (nol) sampai dengan 1 (satu). Semakin tinggi atau semakin mendekati angka 1 nilai $R^{2}$, maka dapat dikatakan semakin baik hasil regresi tersebut. Berdasarkan hasil yang perhitungan pada lampiran 3 diperoleh nilai koefisien determinasi $R$-squared untuk masing-masing perusahaan sebesar $12,75 \%$ dan $82,52 \%$, dimana sisanya dipengaruhi oleh variabel lain diluar model penelitian. Jika dilihat model yang paling kuat dalam menjelaskan ERC adalah model (2) untuk perusahaan keuangan yakni sebesar 82,52\%. Hal ini menunjukkan persistensi laba, kulitas akrual dan fair value mampu menjelaskan atau mempengaruhi ERC.

\section{Uji F}

Uji F dilakukan untuk menguji secara bersamaan variabel independen apakah mampu menjelaskan variabel dependen dengan baik dan untuk menguji apakah model yang digunakan telah fix atau tidak. Kriteria perhitungan uji $\mathrm{F}$ adalah jika $\mathrm{F}$-hitung $>$ F-tabel atai sig $<0,05$. Hasil uji $\mathrm{F}$ pada penelitian ini dapat dilihat pada lampiran 3. Berdasrkan hasil perhitungan dapat disimpulkan model (1) dan (2) untuk perusahaan manufaktur dan keuangan telah menunjukkan tingkat yang baik (good overall model fit) sehingga model regresi dapat digunakan untuk memprediksi ERC pada perusahaan keuangan. 


\section{Uji Hipotesis}

Pengujian hipotesis atau uji-t dimaksudkan untuk mengetahui atau menguji signifikansi antara variabel bebas dengan variabel terikat dengan asumsi variabel lain konstan. Uji- $t$ dapat dilakukan dengan rumus :

$$
t=\frac{\beta n}{S \beta n}
$$

Berdasarkan pada penelitian ini dapat dilihat pada lampiran 3, diketahui bahwa hipotesis 1 untuk perusahaan manufaktur dan keuangan memiliki nilai signifikan $>0,05$, yang menyebabkan hipotesis 1 ditolak untuk kedua sektor perusahaan. Hipotesis 2 untuk perusahaan manufaktur menunjukkan nilai signifikansi $>0,05$, yang menyebabkan hipotesis 2 ditolak untuk perusahaan manufaktur tetapi diterima untuk perusahaan keuangan karena nilai signifikansi $<0,05$.

\section{Pengaruh Persistensi Laba Terhadap ERC}

Berdasarkan hasil analisis statistik dalam penelitian ini, ditemukan hasil bahwa persistensi laba tidak berpengaruh signifikan terhadap kedua sektor perusahaan. Hasil statistik menunjukkan bahwa persistensi laba yang di lihat melalui laba komprehensif yang diukur menggunakan koefisien regresi antar laba, menjukkan hasil negatif tidak signifikan pada perusahaan manufaktur dan positif tidak signifikan pada perusahaan keuangan.

Hal ini dapat terjadi karena motivasi investor dalam investasinya bukan untuk mendapatkan keuntungan jangka panjang melainkan untuk mendapatkan capital gain (Palupi, 2006). Faktor persistensi laba yang menjadi prediktor laba yang akan datang mempunyai prespektif jangka panjang untuk mendapatkan yield dari investasi yang dilakukan, dengan demikian bagi investor yang cenderung mencari capital gain tidak terlalu memperhatikan persistensi laba suatu perusahaan. Hal ini berdampak kepada harga saham sehingga respon investor sekitar tanggal publikasi laba tidak tergambar melalui ERC.

\section{Pengaruh Kulitas Akrual terhadap ERC}

Berdasarkan hasil analisis statistik dalam penelitian ini, ditemukan hasil bahwa kualitas akrual tidak berpengaruh terhadap perusahaan pada sektor manufaktu tetapi berpengaruh positif signifikan pada perusahaan sektor keuangan. Perbedaan ini dapat disebabkan oleh Investor pada perusahaan keuangan lebih memperhatikan kualitas akrual dikarenakan pada perusahaan keuangan terdapat kemugkinan adanya accrual discerionary yang lebih besar karena dalam kegiatan operasionalnya perusahaan keuangan tergolong sering melakukan transaksi atau investasi pada instrumen keuangan, sehingga dianggap perusahaan keuangan lebih high risk exposured (Rosyadi, 2014).

Investor yang lebih memperhatikan kulitas akrual perusahaan ini akan menyebabkan adanya pergerakan harga saham sekitar tanggal laporan keuangan yang tergambar melalui ERC. Dalam kondisi perusahaan manufaktur yang kegiatan operasionalnya dapat dikatakan cenderung stabil maka kemungkinan untuk adanya accrual discerionary cenderung rendah. Investor pada perusahaan manufaktur tidak begitu memperhatikan kualitas akrual perusahaan manufaktur, hal ini berdampak tidak terjadikan perubahan harga saham sekitar tanggal publikasi laporan keungan yang tergambar melalui ERC. 


\section{SIMPULAN, KETERBATASAN DAN SARAN Simpulan}

Berdasarkan hasil pengujian didapatkan hasil bahwasannya persistensi laba pada perusahaan manufaktur berpengaruh negatif dan tidak signifikan terhadap ERC. Hal ini ditunjukkan dengan koefisien regresi sebesar -0.205712, nilai t-hitung -0.903609 dan tingkat signifikansi sebesar 0.3712 yang lebih besar dari tingkat signifikan yang diharapkan yakni 5\%. Sedangkan pada perusahaan keuangan persistensi laba berpengaruh positif tidak signifikan terhadap ERC. Ditunjukkan dengan koefisien regresi sebesar 2,369392, nilai t-hitung 2,575783 dan tingkat signifikansi sebesar 0,0616 yang lebih besar dari 5\% sehingga hipotesis pertama ditolak untuk kedua sektor perusahaan.

Kualitas akrual pada perusahaan manufaktur berpengaruh negatif tidak signifikan terhadap ERC. Hal ini ditunjukkan dengan koefisien regresi sebesar -0.297380, nilai t-hitung 1.779326 dan tingkat signifikansi sebesar 0.0823 yang lebih besar dari tingkat signifikan yang diharapkan yakni 5\% sehingga hipotesis dua ditolak untuk perusahaan manufaktur. Sedangkan pada perusahaan keuangan kualitas akrual berpengaruh positif dan signifikan terhadap ERC. Hal ini ditunjukkan dengan koefisien regresi sebesar sebesar 1.122266, nilai t-hitung 2.761902 dan tingkat signifikansi sebesar 0.0408 yang lebih dari 5\% sehingga hipotesis dua diterima untuk perusahaan keuangan. Pada penelitian ini memasukkan tiga variabel kontrol yakni ukuran perusahaan, leverage dan risiko sistematik yang dijadikan pengaruhnya netral atau dalam penelitian lain bisa disebut dengan covariates. Penambahan variabel kontrol ini dimaksudkan untuk lebih menjelaskan fenomena dengan lebih optimal.

\section{Keterbatasan}

Dalam penelitian ini masih terdapat beberapa keterbatasan yang masih perlu direvisi bagi peneliti selanjutnya. Hasil penelitian ini masih belum menggambarkan kondisi pasar yang sesungguhnya, hal ini disebabkan karena pada penelitian ini reaksi pasar hanya dilihat dari tiga hari sebelum dan tiga hari sesudah tanggal publikasi laporan keuangan yang belum tentu investor bereaksi pada waktu tersebut dan penelitian ini mengambil sampel dengan metode purposive sampling. penggunaan metode purposive sampling ini berakibat pada kurangnya kemampuan generalisasi dari hasil penelitian.

\section{Saran Untuk Penelitian Selanjutnya}

Berdasarkan hasil penelitian yang telah dikemukakan maka dapat diberikan beberapa saran sebagai berikut :

1. Bagi peneliti selanjutnya, diharapkan dapat melakukan penelitian yang lebih lanjut mengenai earnings response coefficient dengan menambah periode penelitian, menggantu proksi yang digunakan dan menggunakan variabel lain selain yang ada dalam penelitian ini.

2. Bagi perusahaan, diharapkan mampu mengendalikan pihak-pihak yang terlibat dalam pengolahan perusahaan, sehingga dapat meminimalisir terjadinya masalah keagenan (agency problem).

3. Bagi investor, dapat dijadikan sebagai bahan pertimbangan dalam pengambilan keputusan investasi. Dimana investor selain fokus pada informasi angka laba yang disajikan, investor juga dapat mempertimbangkan informasi lainnya seperti kualitas akrual pada suatu perusahaan. 


\section{DAFTAR PUSTAKA}

Adhariani, D. (2014). Tingkat Keluasan Pengungkapan Sukarela Dalam Laporan Tahunan dan hubungannya Dengan Current Earnings Response Coefficient (ERC). Jurnal Akuntansi dan Keuangan Indonesia, 2(1), 24-57.

Beaver, W. H., Clarke, R., \& Wright, W. F. (1979). The association between unsystematic security returns and the magnitude of earnings forecast errors. Journal of accounting research, 316-340.

Bangun, D. S., \& Lestari, J. S. (2014). Analisis Perbedaan Kualitas Laba Sebelum dan Sesudah Adopsi IFRS kedalam PSAK pada Perusahaan Manufaktur yang Terdaftar di Bursa Efek Indonesia. Skripsi S1 Universitas Atma Jaya Yogyakarta yang tidak dipublikasikan.

Belkaoui, Riahi Ahmed. (2006). Accounting Theory, edisi ke 5 buku 1. Jakarta. Salemba Empat.

Gideon, S. B. (2005). Boediono. 2005. Kualitas Laba Laba: Studi Pengaruh Mekanisme Corporate Governance dan Dampak Manajemen Laba Dengan Menggunakan Analisis Jalur", Simposium Nasional Akuntansi VII.

Jung, K., \& Cho, J. (1991). Earnings Response Coefficients: Synthesis of Theory and Empirical Evidence. Journal of Accounting literature, 10(1), 85-116.

Chua, Y. L., Cheong, C. S., \& Gould, G. (2012). The impact of mandatory IFRS adoption on accounting quality: Evidence from Australia. Journal of International accounting research, 11(1), 119-146.

Collins, D. W., \& Kothari, S. P. (1989). An analysis of intertemporal and crosssectional determinants of earnings response coefficients. Journal of accounting and economics, 11(2-3), 143-181.

Darmawan, A. (2013). Pengaruh Adopsi IFRS terhadap Earnings Response Coefficient pada Perusahaan di Inggris dan Jerman. JURNAL AKUNTANSI, EKONOMI dan MANAJEMEN BISNIS| e-ISSN: 2548-9836, 1(1), 46-54.

Dechow, P. M., \& Dichev, I. D. (2002). The quality of accruals and earnings: The role of accrual estimation errors. The accounting review, 77(s-1), 35-59.

Dechow, P. M., \& Ge, W. (2006). The persistence of earnings and cash flows and the role of special items: Implications for the accrual anomaly. Review of Accounting studies, 11(2-3), 253-296.

Dechow, P., Ge, W., \& Schrand, C. (2010). Understanding earnings quality: A review of the proxies, their determinants and their consequences. Journal of accounting and economics, 50(2-3), 344-401.

Delvira, M., \& Nelvirita, N. (2013). Pengaruh Risiko Sistematik, Leverage Dan Persistensi Laba Terhadap Earnings Response Coefficient (ERC). Wahana Riset Akuntansi, 1(1).

Diantimala, Y. (2008). Pengaruh Akuntansi Konservatif, Ukuran Perusahaan, dan Default Risk terhadap Koefisien Respon Laba (ERC). Jurnal Telaah dan Riset Akuntansi, 1(1), 102-122.

Djamaluddin, Subekti. (2008). Analisis Perbedaan Antara Laba Akuntansi dan Laba Fiskal Terhadap Persistensi Laba, Akrual, dan Aliran Kas pada Perusahaan Perbankan yang Terdaftar di Bursa Efek Jakarta. Jurnal Riset Akuntansi Indonesia, Vol. 11, No. 1, Januari 2008, Hal. 52-74.

Doyle, J., Ge, W., \& McVay, S. (2007). Accruals quality and internal control over financial reporting" The Accounting Review, vol. 82. 
Fanani, Z., Ningsih, S., \& Akuntansi, D. (2010). Faktor-faktor penentu kualitas pelaporan keuangan dan kepercayaan investor. SNA XII Palembang.

Financial Accounting Standards Board. (1985). Statement of Financial Accounting Concepts No. 1: Objectives of financial reporting by business enterprises. Financial Accounting Standards Board.

Frankel, R. M., \& Sun, Y. (2018). Predicting accruals based on cash-flow properties. The Accounting Review, 93(5), 165-186.

Francis, J., LaFond, R., Olsson, P. M., \& Schipper, K. (2004). Costs of equity and earnings attributes. The accounting review, 79(4), 967-1010.

Savitri, E., Ratnawati, V., \& Timotius, K. (2014). Pengaruh Asimetri Informasi, Leverage, Kualitas Akrual, dan Profitabilitas terhadap Kualitas Laba (Studi pada Perusahaan Manufaktur yang Terdaftar di Bei 2010-2011). Jurnal Online Mahasiswa Fakultas Ekonomi Universitas Riau, 1(1).

Guay, W., S. P. Kothari, and S., Shu. (2003). Properties of the implied cost of capital using analysts'forecasts. Working paper, University of Pennsylvania, Massachusetts Institute of Technology, and Boston College.

Harahap, K. (2004). Asosiasi Antara Praktik Perataan Laba Dengan Koefisien Respons Laba (The Association between Income Smoothing Practice and Profit Coefficient Response). In Accounting National Symposium VII.

Harahap, S. S. (2004). Teori Akuntansi, Cetakan Ketujuh, Jakarta: PT. Raja Grafindo Persada.

Harimurti, Ambya Arif dan Taufik Hidayat. (2013). Value Relevance atas pelaporan Laba Rugi Komprehensif. Jurnal Akuntansi dan Keuangan Indonesia.

Hartono, J. (2013). Metodologi penelitian bisnis. Yogyakarta: BPFE.

Hayn, C. (1995). The information content of losses. Journal of accounting and economics, 20(2), 125-153.

Indonesia, I. A. (2015). Dewan Standar Akuntansi Keuangan.

Imroatussolihah, E. (2013). Pengaruh risiko, leverage, peluang pertumbuhan, persistensi laba dan kualitas tanggung jawab sosial perusahaan terhadap earning response coefficient pada perusahaan high profile. Jurnal Ilmu Manajemen (JIM), 1(1).

Jang, L., Sugiarto, B., \& Siagian, D. (2007). Faktor-faktor yang mempengaruhi Kualitas Laba pada Perusahaan Manufaktur di BEJ. Jurnal Akuntabilitas, 6(2), 142-149.

Jonas, G. J., \& Blanchet, J. (2000). Assessing quality of financial reporting. Accounting horizons, 14(3), 353-363.

Kieso, Donald E., Jerry J. Weygandt, and Terry D. Warfield. (2011). Intermediate Accounting Vol.1, IFRS edition. New Jersey: John Wiley \& Sons, Inc.

Li, F. (2008). Annual report readability, current earnings, and earnings persistence. Journal of Accounting and economics, 45(2-3), 221-247.

Mulyani, S., Asyik, N. F., \& Andayani, A. (2007). Faktor-Faktor yang Mempengaruhi Earnings Response Coeficient pada Perusahaan yang Terdaftar di Bursa Efek Jakarta. Indonesian Journal of Accounting and Auditing, 11(1).

Nasser, Andison, Etty M. (2017). Operating Cash Flow, Earnings Response Coefficient, and Fixed Asset Revaluation : Study on Manufacturing Company. Etikonomi. Vol. 16(1), April 2017. 
Nicky, P. P. (2009). Analisis Faktor-faktor yang Mempengaruhi Koefisien Respon Laba. Skripsi. STIE Bank BPD Jateng.

No, A. S. (2010). Conceptual framework for financial reporting. Norwalk, CT: FASB.

Novianti, R. (2012). Kajian kualitas laba pada perusahaan manufaktur yang terdaftar di BEI. Accounting Analysis Journal, 1(2).

Noviyanti, Tiolemba dan Erni Ekawati. (2008). Analisis Faktor-faktor yang Mempengaruhi Koefisien Respon Laba pada Perusahaan Manufaktur yang Terdaftar di BEI. Jurnal Riset Akuntansi dan Keuangan. Vol. 4. No. 2.

Nurbaety, L. (2014). PENGARUH PERSISTENSI LABA, KESEMPATAN BERTUMBUH DAN UKURAN PERUSAHAAN TERHADAP EARNINGS RESPONSE COEFFICIENT (Studi Empiris Pada Perusahaan Pertambangan yang Terdaftar di Bursa Efek Indonesia Tahun 2008-2012) (Doctoral dissertation, Fakultas Ekonomi Unpas).

Ogneva, M. (2012). Accrual quality, realized returns, and expected returns: The importance of controlling for cash flow shocks. The Accounting Review, 87(4), $1415-1444$.

Pagalung, G. (2006). Kualitas informasi laba:: Faktor-faktor penentu dan konsekuensi ekonominya (Doctoral dissertation, Universitas Gadjah Mada).

Palupi, M. J. (2006). Analisis Faktor Faktor Yang Mempengaruhi Koefisien Respon Laba Bukti Empiris pada Bursa Efek Jakarta. Jurnal Ekubank, 3, 9-24.

Penman, S. H., \& Zhang, X. J. (2002). Accounting conservatism, the quality of earnings, and stock returns. The accounting review, 77(2), 237-264.

PUTRI, K., \& Kurnia, F. I. R. S. T. Y. (2014). Menguji Perubahan Kualitas Akrual dan Relevansi Nilai Laporan Keuangan Sebelum dan Sesudah Full Adopsi IFRS. Jurnal Akuntansi UNESA, 3(1).

Rahmawati (2012), Teori akuntansi keuangan, edisi pertama, Graha Ilmu,Yogyakarta.

Rosyadi, M. A., \& Anggraita, V. (2014). Relevansu Risiko Pengukuran Laba Bersih, Laba Komprehensif dan Laba Nilai Wajar: Studi pada Bank-Bank yang Terdaftar di BEI. Tugas Akhir, Jakarta: Universitas Indonesia.

Schipper, K., \& Vincent, L. (2003). Earnings quality. Accounting horizons, 17, 97110.

Scott, W. R. (2015). Financial Accounting Theory 7th edition'. NY: Pearson Prentice Hall.

Subekti, I. (2005). Asosiasi antara praktik perataan laba dan reaksi pasar modal di Indonesia. Simposium Nasional Akuntansi VIII, 223-236.

Suwardjono. (2005). Teori Akuntansi : Perekayasaan Laporan Keuangan. Edisi ketiga BPFE Yogyakarta.

Tandelilin, Eduardus. (2010). Portofolio dan investasi (Teori dan Aplikasi). Yogyakarta: Penerbit Kanisius.

Winelfia, D. (2016). RELEVANSI NILAI LABA OPERASI, LABA BERSIH, DAN LABA KOMPREHENSIF (Studi Empiris Perusahaan Keuangan Yang Terdaftar Di BEI Tahun 2014-2016). Jurnal Akuntansi, 6(2).

Wijayanti, Handayani Tri. (2006). Analisis Pengaruh Perbedaan Antara Laba Akuntansi Dan Laba Fiskal Terhadap Persistensi Laba, Akrual, Dan Arus Kas.

Simposium Nasional Akuntansi IX, Padang.

www.idx.co.id

www.yahoofinance.co.id

www.tempointeraktif.co.id 